\title{
Six-month follow up of fissurectomy with or without anoplasty for chronic anal fissure: low recurrence rate and no effect on continence
}

\author{
Prof. Alaa El-Din Hassan Mohamed, Prof. AsemElsani Mohamed, Dr. \\ WaelBarakat Ahmed, Dr. MostafaFarrag Mohammed.
}

\section{Department of general surgery, Sohag university hospitals, Egypt Abstract \\ Introduction}

The management of CAF at a time shifted from surgical to medical treatment; chemical sphincterotomy through nitric oxide (NO) donors, calcium-channel blockers or botulinum toxin combined with stool softeners and life-style changes. In resistant CAF, the surgical choice is necessary. Lateral internal sphincterotomy (LIS) has long been the gold standard. Its early results have been favourable, but there is concern over continence in the long term after LIS. Fissurectomy with or without anoplasty, described in our study is an alternative with no or minimal effect on anal continence.

Aim of the work: This study purpose is to assess the safety and short-term outcome results of fissurectomy with or without anoplasty (simple cutaneous advancement flap) as a sphincter saving surgical technique in chronic anal fissure (CAF) and to compare between both procedures regarding post-operative patient's satisfaction, complications and wound healing.

Method: Thirty-Seven series of patients (18 females), who had undergone fissurectomy with anal dilatation alone (14 patients) or combined with anoplasty (23 patients) for a medically resistant CAF, who were admitted at Sohag university hospitals from July 2016 were included in the study. At a duration of follow-up of 6 months, regular outpatient clinic visits for all patients; assessing postoperative pain (on visual analogue scale), wound healing, recurrence, satisfaction with the operation and faecal continence (on Pescatori score).

\section{Statistical analysis:}

Data were recorded using Microsoft Excel 2010 program (Microsoft Co, USA). Normality of data distribution was checked by Shapiro Wilk test. The box plots were used to identify and exclude outliers.

\section{Results:}

The mean age was $39.9(\mathrm{SD} \pm 11.95)$ years. Thirty-two cases $(86.4 \%)$ were presented at admission with anal pain. Duration of anal fissure ranges from (4-18) months.Five patients had a recurrent CAF $(11.6 \%)$. Twenty-four cases $(64.8 \%)$ had posterior anal fissure. Healing time ranged from 6-12 weeks (mean 9 weeks). First day postoperative pain score ranges from 2-7 degrees and managed by simple analgesics. The $6^{\text {th }}$ week pain score ranges from 0-2 degrees for both groups. After complete healing and following soft diet instructions pain improved significantly. Recurrence occurs in 4 cases $(10.8 \%)$ of a total 37 cases. All recurrence cases improved significantly conservatively by local care and good dietary habits. No reported incontinence to stool at all cases. Thirty cases were satisfied $(81.1 \%)$ with th procedure. 
SOHAG MEDICAL JOURNAL Six-month follow up of fissurectomy with or without anoplasty Vol. 22 No. 2 July 2018 MostafaFarrag Mohammed

\begin{tabular}{|c|c|c|c|c|c|}
\hline Variables & $\begin{array}{l}\text { Anal dilatation } \\
\text { group }(n=14)\end{array}$ & $\begin{array}{c}\text { Anoplasty } \\
\text { group } \\
(\mathbf{n}=\mathbf{2 3})\end{array}$ & $\begin{array}{l}\text { Odd's ratio } \\
(95 \% \mathrm{CI})\end{array}$ & $\begin{array}{c}P \\
\text { value }\end{array}$ & Test used \\
\hline Recovery & $\begin{array}{l}\text { Uncomplicated: } 1(7.14 \%) \text {, } \\
\text { Complicated: } 13(92.86 \%)\end{array}$ & $\begin{array}{c}\text { Uncomplicat } \\
\text { ed: } 4 \\
(17.39 \%) \text {, } \\
\text { Complicated: } \\
19 \\
(82.6 \%)\end{array}$ & $\begin{array}{l}3.42(0.36- \\
32.79)\end{array}$ & 0.38 & \multirow{5}{*}{$\begin{array}{c}\text { Fisher exact } \\
\text { test }\end{array}$} \\
\hline $\begin{array}{c}\text { Delayed healing } \\
\text { (> } 6 \text { wks) }\end{array}$ & $5(35.71 \%)$ & $2(8.7 \%)$ & $\begin{array}{c}5.83(0.95- \\
35.87) \\
\end{array}$ & 0.08 & \\
\hline Recurrence & $2(14.29 \%)$ & $2(8.7 \%)$ & $\begin{array}{c}1.75(0.22- \\
14.1)\end{array}$ & $\mathbf{0}$ & \\
\hline $\begin{array}{l}\text { 24th week flatus } \\
\text { incontinence }\end{array}$ & $2(14.29 \%)$ & $1(4.35 \%)$ & $\begin{array}{l}3.67(0.3- \\
44.73)\end{array}$ & 0.54 & \\
\hline $\begin{array}{l}\text { Minimal Wound } \\
\text { infection }\end{array}$ & $11(78.57 \%)$ & $19(82.6 \%)$ & $\begin{array}{c}0.77(0.15- \\
4.1)\end{array}$ & 1 & \\
\hline
\end{tabular}
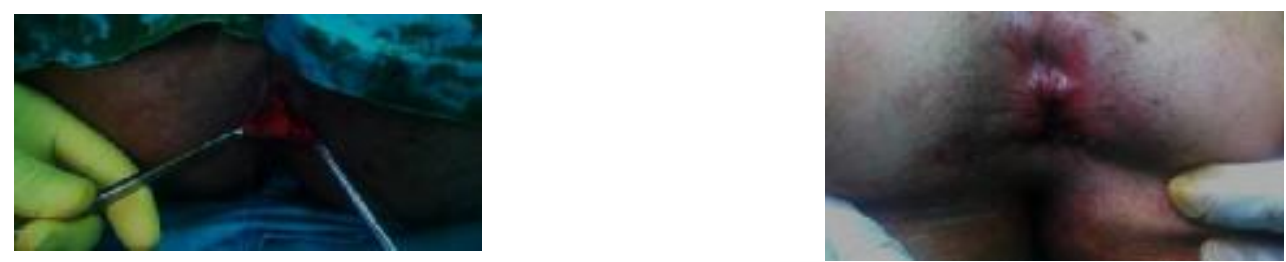

Fig. 1- Fissurectomy with stay suture for later flap

Fig. 2- Anoplasty for posterior CAF

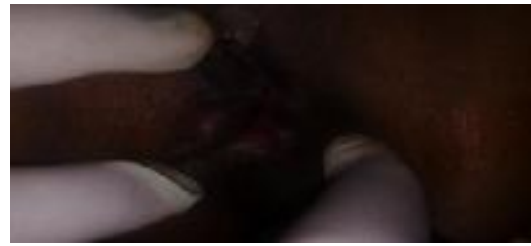

Fig. 3- Healed posterior CAF after

fissurectomywith anoplasty

\section{Discussion:}

Chronic anal fissure is a commonest anal condition of world population and also Egypt. Conservative management is recommended with dietary regimen, creams and oral analgesics as a first line. When conservative measures fail despite of recommended length of therapy, surgical option is offered.Recently, there has been growing interest in the sphincter-sparing techniques, with favorable short-term results.

\section{Conclusion:}

Given its high rate of healing no effect on anal continence, fissurectomy with or without advancement flap for patients with CAF represents a safe, simple and valid sphincter saving procedure to manage resistant CAF successfully.

\section{References}

1- Adegbola, S.O., Sahnan, K., Pellino, G., Tozer, P.J., Hart, A., Phillips, R.K.S., Warusavitarne, J. and Faiz, O.D., 2017. Short-term efficacy and safety of three novel sphincter-sparing techniques for anal fistulae: a systematic 
SOHAG MEDICAL JOURNAL Six-month follow up of fissurectomy with or without anoplasty

review. Techniques

coloproctology, 21(10), pp.775-782.

2- Newman, P.A. and Dixon, T., 2017. Benign anorectal conditions. Surgery (Oxford), 35(8), pp.443-450.

3- Patti, R., Guercio, G., Territo, V., Aiello, P., Angelo, G.L. and Di Vita, G., 2012. Advancement flap in the management of chronic anal fissure: a prospective study. Updates in surgery, 64(2), pp.101-106.

4- Sahebally, S.M., Walsh, S.R., Mahmood, W., Aherne, T.M. and Joyce, M.R.,
2017. Anal advancement flap versus lateral internal sphincterotomy for chronic anal fissure-a systematic review and meta-analysis. International Journal of Surgery.

5- Schornagel, I.L., Witvliet, M. and Engel, A.F., 2012. Five-year results of fissurectomy for chronic anal fissure: low recurrence rate and minimal effect on continence. Colorectal Disease, 14(8), pp.997-1000. 